\title{
Assesment of Anticarcinogenic Activities of the Soft Coral Sarcophyton Glaucum Extract on Mouse Leukemia In Vivo and In vitro
}

\author{
Najah Mohammed Al-baqami ${ }^{1}$, Osama Abdullah Abuzinadah ${ }^{1}$, M-Zaki Mustafa ELassouli ${ }^{2}$, Mohammed A. Almatry ${ }^{1}$, \\ Yasir Anwar ${ }^{1}$ and Sufian ElAssouli ${ }^{1.2}$ \\ ${ }^{1}$ Biological Sciences Department, Faculty of Science, King Abdulaziz University, Jeddah, Saudi Arabia . \\ ${ }^{2}$ King Fahd Medical Research Center, King Abdulaziz University, Jeddah, Saudi Arabia. \\ E. mail : najah-bio@hotmail.com
}

\begin{abstract}
Marine environment biodiversity opens up new horizons in the quest for bioactive compounds that could be utilized as antitumor agents. Soft Coral Sarcophyton glaucum is an important folk medicinal marine. It has anti-oxidant, anticarcinogenic. The objectives of present study are to investigatimg in vitro the antiproliferative activity of sarcophine extract on mouse Leukemia cells (L1210), also, we shall evaluate in vivo the antitumor activity of the soft coral S. glaucum extract against Mouse Leukemia cells (L1210), on mice (Swiss albino mice). The antiproliferative and cytotoxic activities of the S. glaucum were determined using the trypan blue dye exclusion and the WST-1 cell proliferation tests. The underlying possible mechanism of cell death was investigated whether it is necrotic or apoptotic by single cell gel electrophoresis (comet assay) and dual acridine orange/ethidium bromide (AO/EB) staining. The antitumor activity of the S. glaucum extract against mouse leukemia cell line, L1210, grown as ascites in mouse model. In vitro Results showed that S. glaucum inhibited L1210 cancer cells proliferation and induced apoptosis and that the apoptotic activities. The mechanism underlying cell death was due to induction of apoptosis, which was associated by DNA damage and morphological changes of the treated cells. In vivo study indicated that S. glaucum has ability to suppress cancer progression in treated animals. These findings indicate that the S. glaucum extract can be a candidate agent for fighting cancer.
\end{abstract}

Keywords: . Soft Coral, anti-oxidant, anti-carcinogenic.

\section{Introduction}

Natural products derived from marine ecosystem are diverse in their biological activity as well as chemical structures. In this regard, The Red Sea acts as a rich source of marine bio-diversity serving an epicenter of marine natural products. Nevertheless $40 \%$ of the 180 soft coral species that have been identified worldwide so far are present in Red Sea $\left.{ }^{[1}\right]$. Soft corals are invertebrates present in marine ecosystem that produce a wide range of terpenoid metabolites. The terpenes produced are usually cembranoids, used to defend against encroaching corals and its natural predators ${ }^{[2]}$. Genus, Sarcophyton of soft corals is predominantly rich in cembrane terpenes ${ }^{[3]}$. Cembranoids have a 14-membered macro cyclic skeleton exhibiting a broad range of biological activity. This includes anti-tumor, neuroprotective, antimicrobial, calciumantagonistic, and anti-inflammatory activities ${ }^{[4 ; 5 ; 6 ; 7]}$. Since 1998 studies have focused on the cembranoid diterpene sarcophine due to its potential role as chemo-preventive ${ }^{[8]}$, cytotoxic and antimicrobial agent ${ }^{[9]}$. Additionally, it also exhibits competitive cholinesterase inhibition ${ }^{[10]}, \quad$ noncompetitive phosphofructo- kinase inhibition ${ }^{[11]}$, and 
$\mathrm{Na}^{+}, \mathrm{K}^{+}$-ATPase inhibition ${ }^{[12]}$. Accordingly, recent studies concerning the use of soft corals as potential source of treatment for numerous human diseases have shown that sarcophine and sarcophine derivatives (e.g., hydroxylated sarcophine) are potentially anticancer metabolites $[8 ; 9 ; 13 ; 14 ; 15]$. Growing interest in chemoprevention of cancer using on natural compounds that delay or reverse cancer development ${ }^{[16]}$ has led to the discovery of thousands of marine natural products in a span of 20 years, most of which have been assayed as anticancer agents $\left.{ }^{[17 ; 7 ; 13}\right]$. In vitro studies show that metabolites isolated from soft corals could inhibit the process of carcinogenesis by enhancing the activity of detoxification enzymes such as glutathione $S$-transferases (GSTs), quinone reductase (QR), and epoxide hydrolase $(\mathrm{mEH})$ in addition to inbition of cytochrome $\mathrm{P}_{450} 1 \mathrm{~A}$ activity.

In this study, we used extract isolated from soft coral Sarcophyton glaucum (sarcophine) of the Red Sea and studied in vitro anti-proliferative properties. The extract is an excellent antitumor agent inducing apoptosis in mouse leukemia cells (L1210).

\section{Materials \& Methods}

\subsubsection{Soft Coral Material}

Soft coral Sarcophyton glaucum (S. glaucum) was collected from the Red Sea coast, North of Jeddah, Saudi Arabia $\left(21^{\circ} 29^{\prime} 33^{\prime \prime} \mathrm{N}\right.$, $\left.39^{\circ} 11^{\prime} 25^{\prime \prime} \mathrm{E}\right)$, at a depth of $5 \mathrm{~m}$. The sample was collected and identified by Dr. Yahia Folos, Faculty of Marine Sciences, King Abdulaziz University. After collection, this material was immediately subjected to extraction. A voucher specimen (SC-2014-1) was deposited in the Faculty of Science, King Abdulaziz University, Jeddah, Saudi Arabia.

\subsubsection{Extraction and Isolation}

The collected sample was subjected to extraction by mincing it and then using diethyl ether as a solvent. The yield was viscous blackish residue, which was further purified by preparative thin layer chromatography (PTLC) and re-purified by employing Sephadex LH-20 (F 1/4 5, L 1/4 10 $\mathrm{cm}, 5 \mathrm{~mL}$ each) using a mixture of methanol and Chloroform $\mathrm{MeOH}$ : $\mathrm{CHCl}_{3}$ (9:1).

\subsubsection{Tumor Cell Lines and Cell Culture}

mouse Leukemia cells line (L1210), obtained from King Fahd Medical Research Center, King Abdulaziz University, Jeddah, were used to study the antitumor activity of different fractions. The mouse leukemic cells, L1210 cells were grown and maintained in RPMI 1640 medium supplemented with 10\% (v/v) horde serum, 1\% penicillin streptomycin antibiotics (10,000 units/ml and 10,000 $\mu \mathrm{g} / \mathrm{ml}$ ) respectively, in tissue culture flasks at $37^{\circ} \mathrm{C}$ in $95 \%$ air and $5 \% \mathrm{CO}_{2}$.

\subsubsection{Trypan Blue exclusion test to assess cell viability}

The effect of $S$. glacum extract on proliferation on L1210 cells was observed using $0.4 \%$ trypan blue exclusion test. Cells were cultured in 24 well plates at density of $5 \times 10^{4} /$ cells and treated with corresponding concentrations of the extract $(25,50,75$ and $100 \mu \mathrm{g} / \mathrm{ml}$ ) for 24, 48 and 72 hours. Cells were collected and mixed with 1:1 trypan blue for $5 \mathrm{~min}$. Afterwards the cells were counted 
using hemocytometer under light microscope to observe the percentage of live cells.

\subsubsection{Comet Assay}

L1210 cells were plated in (4) 6 well plates at a density of $5 \times 10^{4} / \mathrm{cells} / \mathrm{ml}$ for $24 \mathrm{~h}$. Cells were treated with S. glaucum extract at concentrations of $25,50,75$ and $100 \mu \mathrm{g} / \mathrm{ml}$ for 24h. Mincing solution consisting of HBSS $\mathrm{Ca}^{++}, \mathrm{Mg}^{++}$free with $20 \mathrm{mM}$ EDTA and $10 \%$ DMSO, pH 7.0 - 7.5 was added, and cells were scraped and centrifuged at 400xg for 5 minutes, cells were washed once with ice cold $1 \mathrm{X}$ PBS $\left(\mathrm{Ca}^{++}\right.$and $\mathrm{Mg}^{++}$free $)$and approximately 10,000 cells/slide were mixed with $0.1 \mathrm{ml}$ of $1 \%$ low melting point agarose and loaded on comet slides (Trevigen, USA), in duplicate. The gel was allowed to solidify. Afterwards the slides were placed in freshly prepared cold lysis solution containing $2.5 \mathrm{M}$ $\mathrm{NaC} 1,100 \mathrm{mM} \mathrm{Na}_{2}$ EDTA, 10mM Tris, $\mathrm{pH}$ $10,1 \%$ sodium sarcosine, $1 \%$ Triton $\mathrm{X}-100$ and $10 \%$ DMSO and incubated at $4{ }^{\circ} \mathrm{C}$ for 30 min. Slides were later placed horizontally in electrophoresis apparatus filled with freshly prepared alkaline solution, $\mathrm{pH} \geq 13$ (300 $\mathrm{mMNaOH}, 1 \mathrm{mM}$ EDTA) for 20 minutes to unwinding DNA, and electrophoresed at 0.9 Volt $/ \mathrm{cm}$ for 20 minutes at room temperature. Following electrophoresis slides were rinsed for 5 minutes three times with neutralizing solution (0.4 M Tris buffer $\mathrm{pH} 7.4)$ and then immersed in absolute ethanol for 5 minutes for drying and DNA precipitation. Slides were stained with $20 \mu \mathrm{g} / \mathrm{ml}$ ethidium bromide and observed under fluorescence microscope.

\subsubsection{Fluorescence Microscopic Analysis of Cell Death}

Acridine orange/ethidium bromide $(\mathrm{AO} / \mathrm{EB})$ double staining assay was performed. Briefly, cells treated with corresponding concentrations of the extract were incubated for $30 \mathrm{~min}, 1,2$ and $3 \mathrm{hr}$. Cell were centrifuged for $10 \mathrm{~min}$ at $1500 \mathrm{rpm}$. Pellets were suspended in $0.1 \mathrm{ml}$ of medium with $0.025 \mathrm{ml}$ of the staining mixture (acridine orange and ethidium bromide, $0.1 \mathrm{mg} \mathrm{ml} / 1$ in PBS). Cells were placed on slides and observed under a fluorescence microscope. Images were obtained at $400 \times$ magnification.

\subsection{In vivo Study the Effect of L1210 cell on ascites and sold Tumor}

\subsubsection{Animal Model}

A total of 30 Male BALB/c mice, aged, 8 to 10 weeks, with approximately 25-30 g weight were purchased from the Animal House in King Fahad Medical Research center KFMRC, King Abdulaziz University KAU, Jeddah. All mice were healthy and housed according to the guidelines provided by the institution. Mice were allowed to acclimatize to their surroundings for 7 days prior to the experiment.

\subsubsection{Acute Toxicity Studies}

The extract of S. glaucum was evaluated for toxic effects on four mice. Incremental does of $75,100,150$ and $200 \mu \mathrm{g} / \mathrm{ml}$, was injected intra-peritoneal. Observations were made and 
recorded systematically and continuously for a week and injection.

\subsubsection{Transplantable models}

A total of 40 male Swiss albino mice were divided into 4 groups $(n=10)$ with an average weight of 22-28 gm. Around $1 \times 10^{4}$ cells were injected intraperitoneal (i.p) in 40 mice,

\subsubsection{Ascites Model and Therapeutic Schedule}

Male swiss albino mice were randomly divided into 4 groups designated as Gp1, Gp2, Gp3, and Gp4 (n=10 mice). Gp1 did not receive any treatment or tumor cell injection. Both Gp 2 and Gp3 received intraperitoneal injections for 5 days. While Gp4 were injected with cells and $75 \mu \mathrm{g} / \mathrm{ml}$ of extract.

\section{Results}

\subsection{Trypan blue exclusion dye}

The effect of the extract S. glaugum on the viability of L1210 cells was evaluated by trypan blue dye exclusion. Cells were treated with increasing concentrations of the $(25,50$, 75,100 and $500 \mu \mathrm{g} / \mathrm{ml}$ ) for 24,48 and 72 hours. The result showed that the incubation with the extract efficiently inhibited cell viability in a dose-dependent manner. The $\mathrm{IC}_{50}$ (concentration which inhibits $50 \%$ of cell growth) after 72 hours of incubation was 75 $\mu \mathrm{g} / \mathrm{ml}$ the concentration of $100 \mu \mathrm{g} / \mathrm{ml}$ significantly decreased proliferation after 48 hours (Table 1 and figure 1). There was no significant change in $\mathrm{IC}_{50}$ value at concentration $(50 \mu \mathrm{g} / \mathrm{ml})$ after 48 and 72 hours' the extract $S$. glaugum was used as the reference drug and it produced $100 \%$ cytotoxicity at the concentrations $(500 \mu \mathrm{g} / \mathrm{ml})$ after 24 hours. Concentration $(25 \mu \mathrm{g} / \mathrm{ml})$ incubation compared with untreated control cells was significantly increased with time in this order 24,48 and 72 hours.

\subsection{Single cell gel electrophoresis (Comet assay)}

Representative comet assay images of control and S.glaucum treated L1210 cells are presented in (Table: 2 ). Our results indicate that the cell distribution is does dependent. A significant difference was observed between the basal value of the untreated (control) cells and the cells treated with extract S.glaucum. There was a gradual increase in the percentage of damaged cells in a dose dependent manner. The mean comet moments (Table: 2 ) of cells treated with $100 \mu \mathrm{g} / \mathrm{ml}$ was 17.77 compared with 0.02 for control cells. These results showed a significant $(p<0.05)$ increase of DNA damage in cells treated with extract of S. glaucum Also, the comet tail moment increased from 0.02 in the control to 29.74. In comparison between dose $75 \mu \mathrm{g} / \mathrm{ml}$ and $100 \mu \mathrm{g} / \mathrm{ml}$ results showed a significant ( $\mathrm{p}$ $<0.05$ ) increase of DNA damage. The percentage of cells with comet in the $\mathrm{S}$. glaucum treated cells reached up to $91 \%$ at a dose of $100 \mu \mathrm{g} / \mathrm{ml}$, compare with the control which showed comet in $0-3 \%$ of the cells during 120-minute duration. There was a gradual increase in the comet tail length, tail moment, tail arm, and percentage of DNA cleavage of L1210 cells, with increasing doses of extract S.glaucum as seen Figure(3). Necrosis could also be observed for cells treated with $100 \mu \mathrm{g} / \mathrm{ml}$ (Figure: 3). 


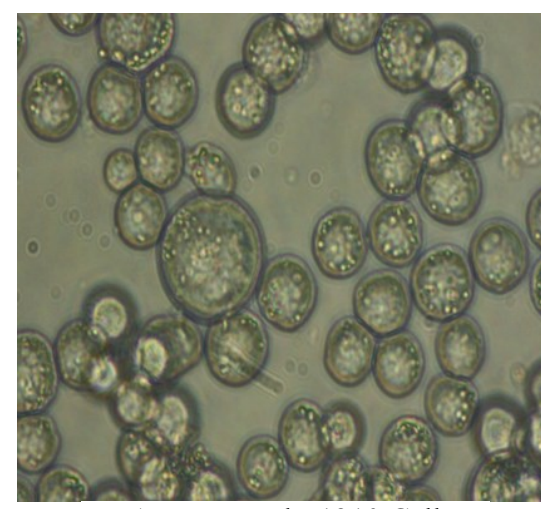

A: Untreated L1210 Cell

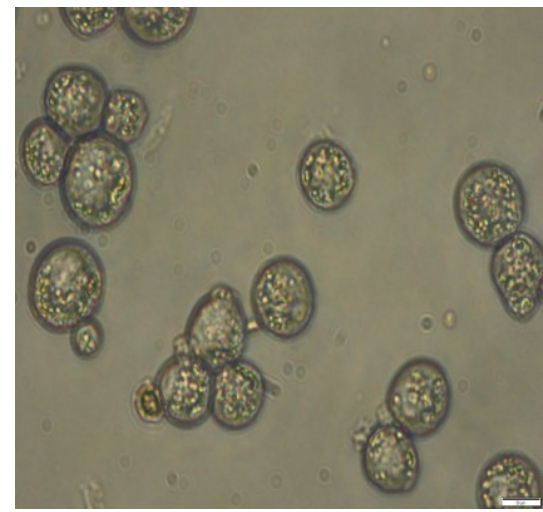

C: L1210 Treated With $75 \mu \mathrm{g} / \mathrm{ml}$

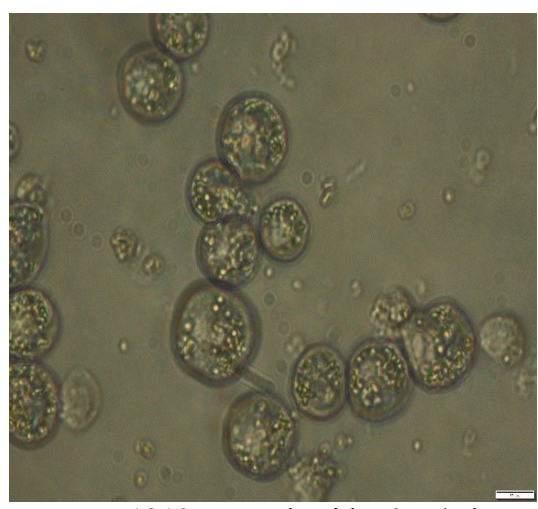

B: L1210 Treated With $50 \mu \mathrm{g} / \mathrm{ml}$

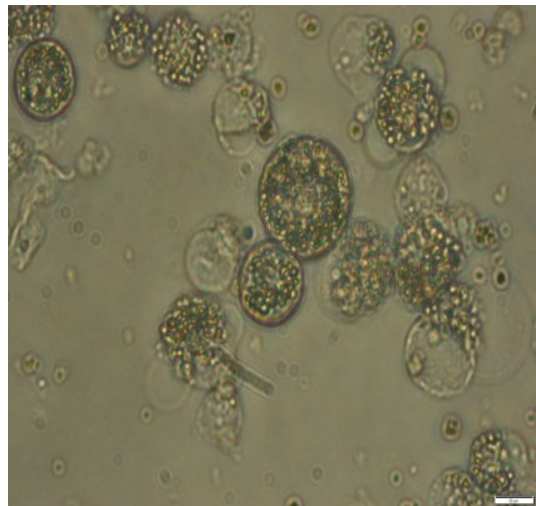

D: L1210 Treated With $100 \mu \mathrm{g} / \mathrm{ml}$

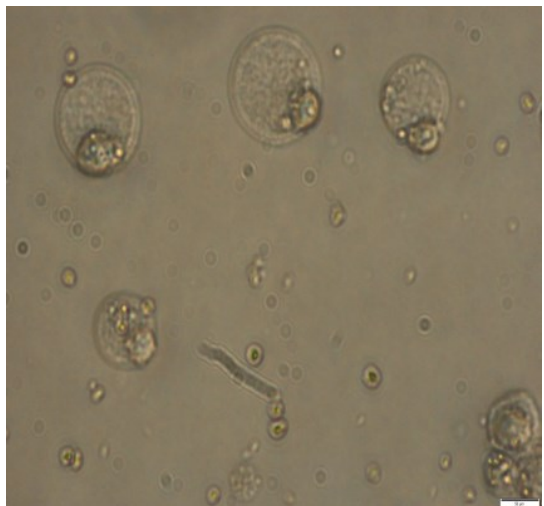

E: L1210 Treated With $500 \mu \mathrm{g} / \mathrm{ml}$

Figure : (1) Photographic images stained with Trypan blue showing the cytotoxicity of S.glaucum on L1210 cells. 
Table: (1) Effects of S.glaucum on L1210 cells viability assessment by a trypan blue exclusion staining. The results are the mean \pm SD of triplicate independent experiments. Results show that strong of S.glaucum inhibits viability and proliferation of 11210 cell in a concentration-dependent manner

\begin{tabular}{|c|c|c|c|c|c|c|}
\hline & \multicolumn{2}{|c|}{ Day 1} & \multicolumn{2}{|c|}{ Day 2} & \multicolumn{2}{|c|}{ Day 3} \\
\hline $\begin{array}{c}\text { Extract } \\
\text { concentration }\end{array}$ & $\begin{array}{l}\text { Mean } \pm \text { SD } \\
\text { (cells/ml) }\end{array}$ & $\begin{array}{c}\text { Mean } \\
\text { Number of } \\
\text { cells/ml1 }\end{array}$ & $\begin{array}{l}\text { Mean } \pm \text { SD } \\
(\text { cells } / \mathrm{ml})\end{array}$ & $\begin{array}{c}\text { Mean } \\
\text { Number of } \\
\text { cells/ml1 }\end{array}$ & $\begin{array}{l}\text { Mean } \pm \text { SD } \\
\text { (cells/ml) }\end{array}$ & $\begin{array}{c}\text { Mean } \\
\text { Number of } \\
\text { cells/ml1 }\end{array}$ \\
\hline $\begin{array}{c}\text { Untreated } \\
(\text { control cells) }\end{array}$ & $6.00 \pm 0.00$ & $12 \times 10^{4}$ & $12.00 \pm 0.00$ & $24 \times 10^{4}$ & $23.50 \pm 0.71$ & $47 \times 10^{4}$ \\
\hline $\begin{array}{l}\mathbf{2 5}(\mu \mathrm{g} / \text { well }) \\
\text { Significance }\end{array}$ & $\begin{array}{c}5.50 \pm 0.71 \\
\mathbf{0 . 0 0 0 1}\end{array}$ & $11 \times 10^{4}$ & $\begin{array}{c}9.00 \pm 0.00 \\
\mathbf{0 . 0 0 0 1}\end{array}$ & $18 \times 10^{4}$ & $\begin{array}{c}11.00 \pm 1.41 \\
\mathbf{0 . 0 0 0 1}\end{array}$ & $22 \times 10^{4}$ \\
\hline $\begin{array}{l}\mathbf{5 0}(\mu \mathrm{g} / \text { well }) \\
\text { Significance }\end{array}$ & $\begin{array}{c}3.00 \pm 0.00 \\
\mathbf{0 . 0 0 1}\end{array}$ & $6 \times 10^{4}$ & $\begin{array}{c}2.50 \pm 0.71 \\
\mathbf{0 . 0 0 0 1}\end{array}$ & $5 \times 10^{4}$ & $\begin{array}{c}2.50 \pm 0.71 \\
\mathbf{0 . 0 0 0 1}\end{array}$ & $5 \times 10^{4}$ \\
\hline $\begin{array}{l}75 \text { ( } \mu \mathrm{g} / \text { well }) \\
\text { Significance }\end{array}$ & $\begin{array}{c}2.50 \pm 0.71 \\
\mathbf{0 . 0 0 0 1}\end{array}$ & $5 \times 10^{4}$ & $\begin{array}{c}2.00 \pm 0.00 \\
\mathbf{0 . 0 0 0 1}\end{array}$ & $4 \times 10^{4}$ & $\begin{array}{c}1.00 \pm 0.00 \\
\mathbf{0 . 0 0 0 1}\end{array}$ & $2 \times 10^{4}$ \\
\hline $\begin{array}{l}100(\mu \mathrm{g} / \text { well }) \\
\text { Significance }\end{array}$ & $\begin{array}{c}1.50 \pm 0.71 \\
\mathbf{0 . 0 0 0 1}\end{array}$ & $3 \times 10^{4}$ & $\begin{array}{c}1.00 \pm 0.00 \\
\mathbf{0 . 0 0 0 1}\end{array}$ & $2 \times 10^{4}$ & $\begin{array}{c}0.50 \pm 0.00 \\
\mathbf{0 . 0 0 0 1}\end{array}$ & $1 \times 10^{4}$ \\
\hline $\begin{array}{l}\mathbf{5 0 0}(\mu \mathrm{g} / \text { well }) \\
\text { Significance }\end{array}$ & $\begin{array}{c}0.00 \pm 0.00 \\
\mathbf{0 . 0 0 0 1}\end{array}$ & $0.00 \times 10^{4}$ & $\begin{array}{c}0.00 \pm 0.00 \\
\mathbf{0 . 0 0 0 1}\end{array}$ & $0 \times 10^{4}$ & $\begin{array}{c}0.00 \pm 0.00 \\
\mathbf{0 . 0 0 0 1}\end{array}$ & $0 \times 10^{4}$ \\
\hline
\end{tabular}

1. Mean of duplicate experiments.

2.The seeding number of cells is $5 \times 10^{4}$ 

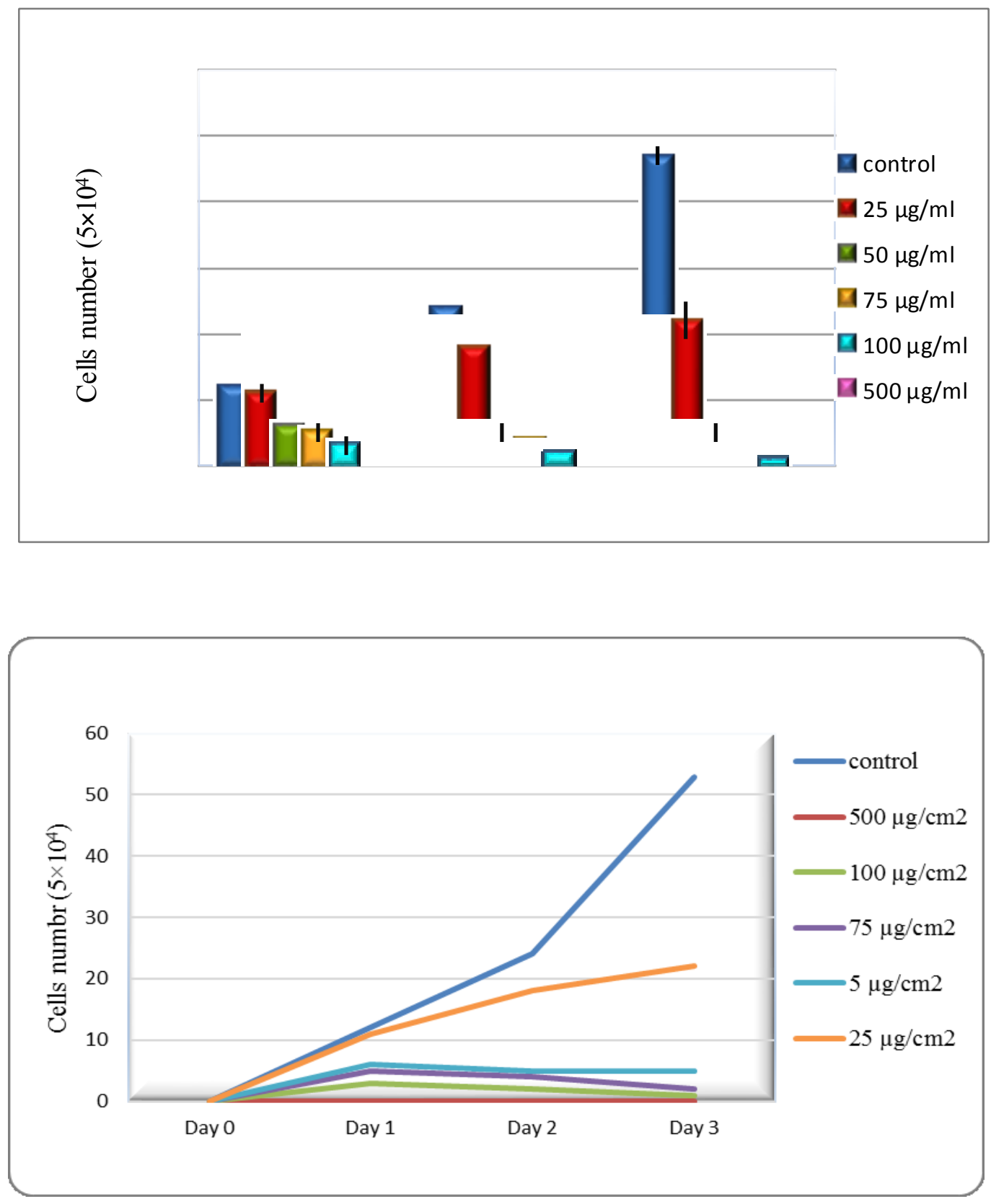

Figure :(2) Effect of S.glaucum on (L1210) cells viability assessment by trypan blue dye exclusion . 


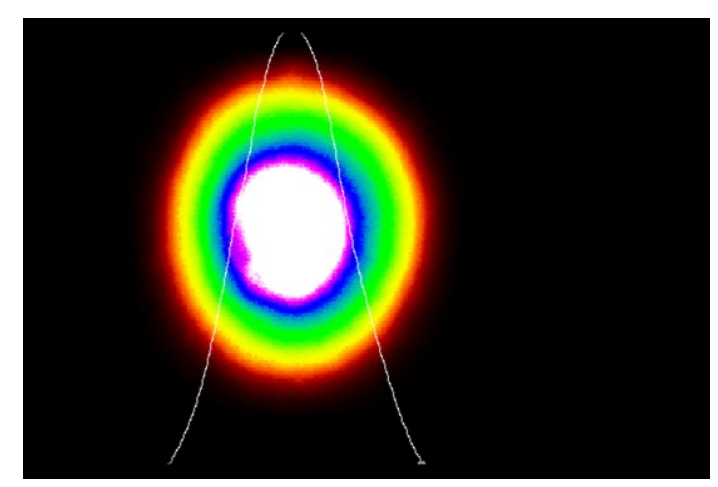

(A): Image of untreated 11210 cell

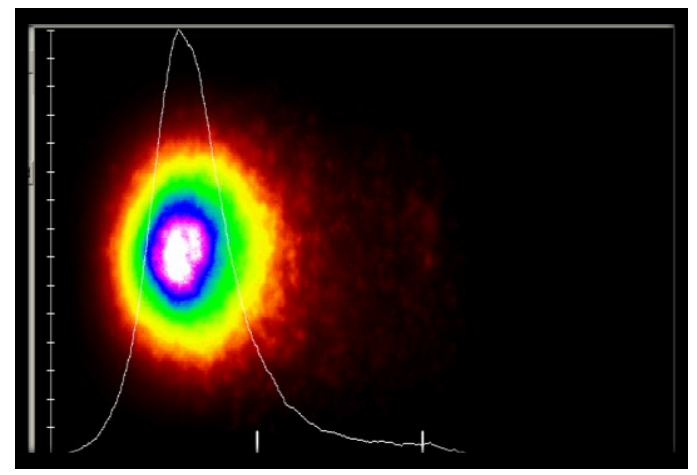

(C): Image of (L1210) cells treated with $75 \mu \mathrm{g} / \mathrm{ml}$

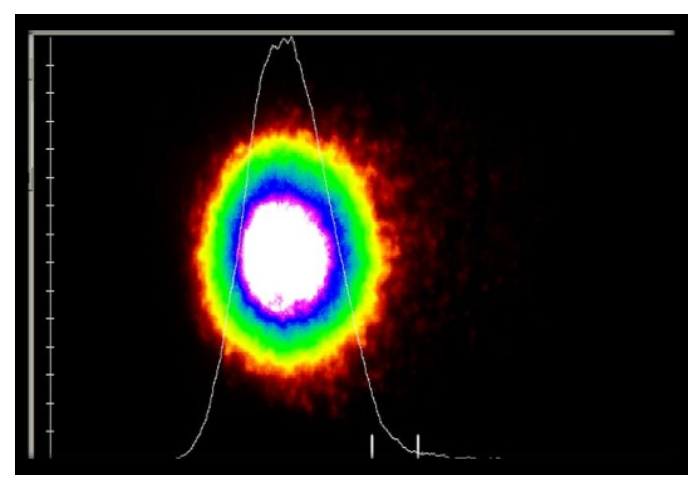

(B): Image of (L1210) cells treated with $50 \mu \mathrm{g} / \mathrm{ml}$

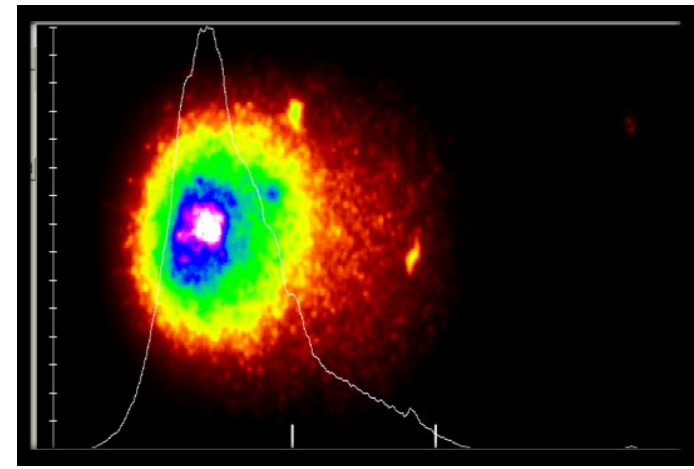

(D1): Image of (L1210) cells treated

with $100 \mu \mathrm{g} / \mathrm{ml}$

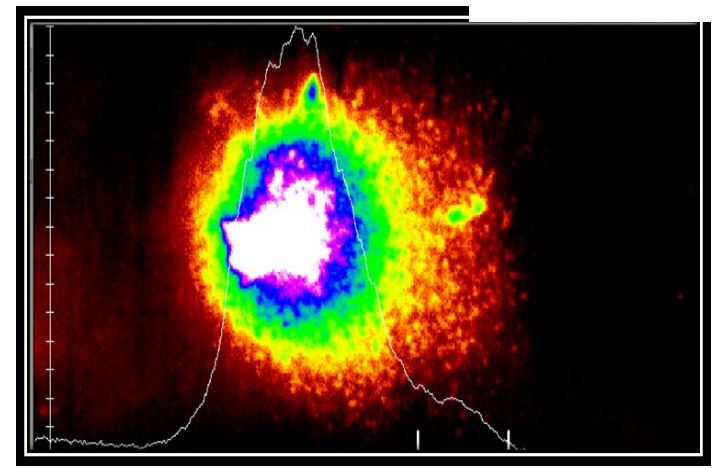

(F): Image show necrotic comet cell showing comet

with no apoptotic bodies at $100 \mu \mathrm{g} / \mathrm{ml}$

Figure: (3) Effect of S. glaucum on (L1210) cells treated for $24 \mathrm{~h}$ then subjected to single cell gel electrophoresis by comet analysis system (A) Control. While (B), (C) and (D1,2) cells exposed to $(50,75$ and $100 \mu \mathrm{g} / \mathrm{ml})$ respectively. 
Table: (2) Genotoxicity of S.glaucum extract on mouse cancer cells L1210 as determined by comet assay

\begin{tabular}{|c|c|c|c|c|c|c|}
\hline \multirow{3}{*}{$\begin{array}{c}\begin{array}{c}\text { Extract } \\
\text { Concentration }\end{array} \\
\mu \mathrm{g} / \mathrm{ml}\end{array}$} & \multicolumn{6}{|c|}{ Treatment time (minute) } \\
\hline & \multicolumn{2}{|c|}{60 minutes } & \multicolumn{2}{|c|}{90 minutes } & \multicolumn{2}{|c|}{120 minutes } \\
\hline & $\begin{array}{l}\text { Percentage } \\
\text { cells with } \\
\text { comet }^{1}\end{array}$ & $\begin{array}{c}\text { Mean comet } \\
\text { moments }\end{array}$ & $\begin{array}{l}\text { Percentage } \\
\text { cells with } \\
\text { comet }\end{array}$ & $\begin{array}{l}\text { Mean comet } \\
\text { moments }\end{array}$ & $\begin{array}{l}\text { Percentage } \\
\text { cells with } \\
\text { comet }\end{array}$ & $\begin{array}{c}\text { Mean comet } \\
\text { moments }\end{array}$ \\
\hline control & $2 \%$ & 0.02 & $2 \%$ & 0.02 & $3 \%$ & 0.03 \\
\hline $50 \mu \mathrm{g} / \mathrm{ml}$ & $40 \%$ & 3.14 & $45 \%$ & 5.71 & $51 \%$ & 11.33 \\
\hline $75 \mu \mathrm{g} / \mathrm{ml}$ & $64 \%$ & 7.14 & $69 \%$ & 13.6 & $75 \%$ & 15.5 \\
\hline $100 \mu \mathrm{g} / \mathrm{ml}$ & $80 \%$ & 17.77 & $85 \%$ & 22.45 & $91 \%$ & 29.74 \\
\hline
\end{tabular}

1. Number of cells of each group is 100

2. Number of cells of each group is 20

\subsection{Fluorescence Microscopic Analysis of Cell Death}

Acridine orange-ethydium bromide (AO/EB) double-staining test evaluated the apoptotic potential of extract S.glaucum on L1210 cells. As shown in Figure-4, different concentrations of S.glaucum extract $(25,50$, 75 and $100 \mu \mathrm{g} / \mathrm{ml}$ ) caused apoptosis whereas no significant apoptosis was detected in the negative control group (Figure:4A) the circular nucleus was uniformly distributed in the center of the cell. Early-stage apoptotic cells, marked by crescent-shaped or granular yellow green $\mathrm{AO}$ nuclear staining, were detected at $50 \mu \mathrm{g} / \mathrm{ml}$ after $1 \mathrm{~h}$ (Figure 4B). Staining was localized asymmetrically within the cells. With increasing concentrations and treatment lengths, the number of early-stage apoptotic cells increased. Late-stage apoptotic cells, with concentrated and asymmetrically localized orange nuclear EB staining, were detected at the concentrations $75 \mu \mathrm{g} / \mathrm{ml}$ after 2h (Figure 4D). Necrotic cells increased in volume and showed uneven orange-red fluorescence at their periphery. The cells appeared to be in the process of disintegrating at the concentrations $100 \mu \mathrm{g} / \mathrm{ml}$ ) after $2 \mathrm{~h}$ (Figure 4D). 


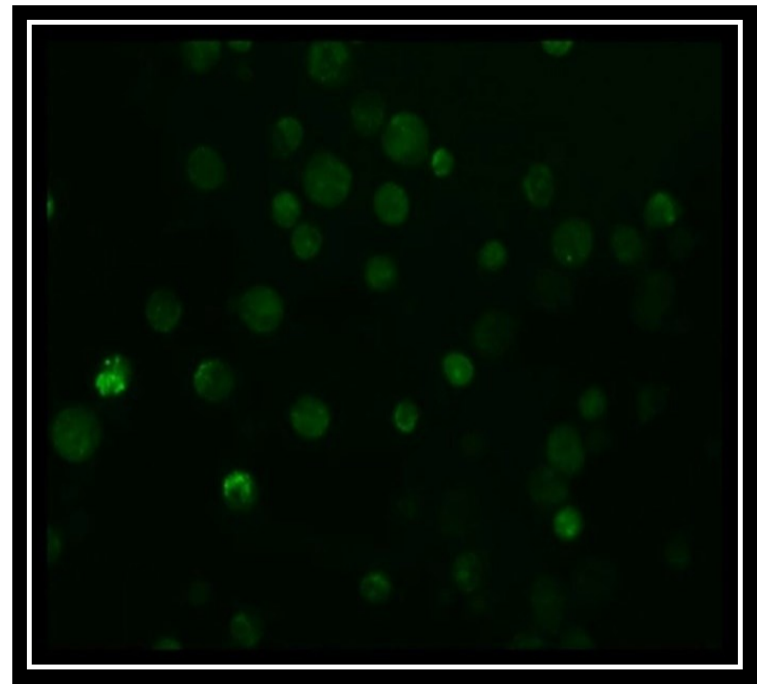

(A)

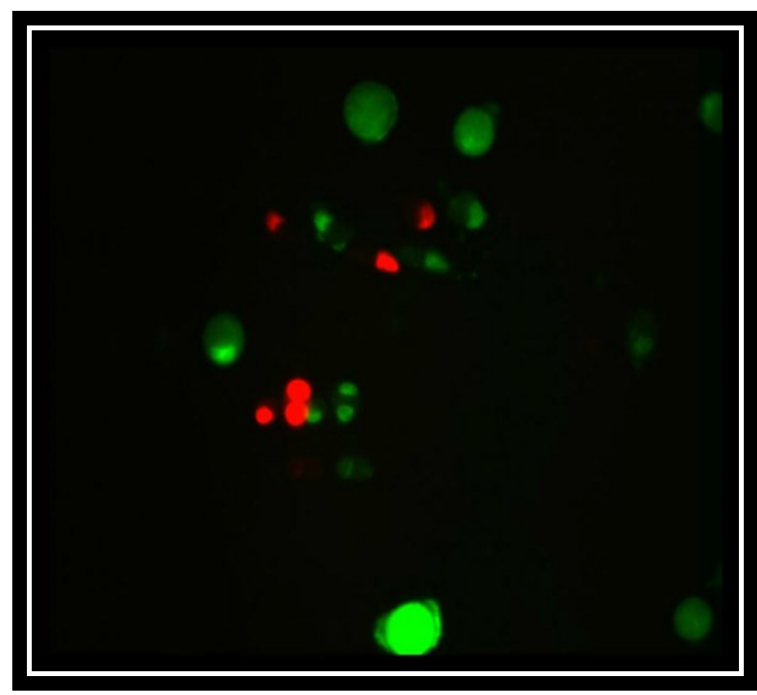

(C)

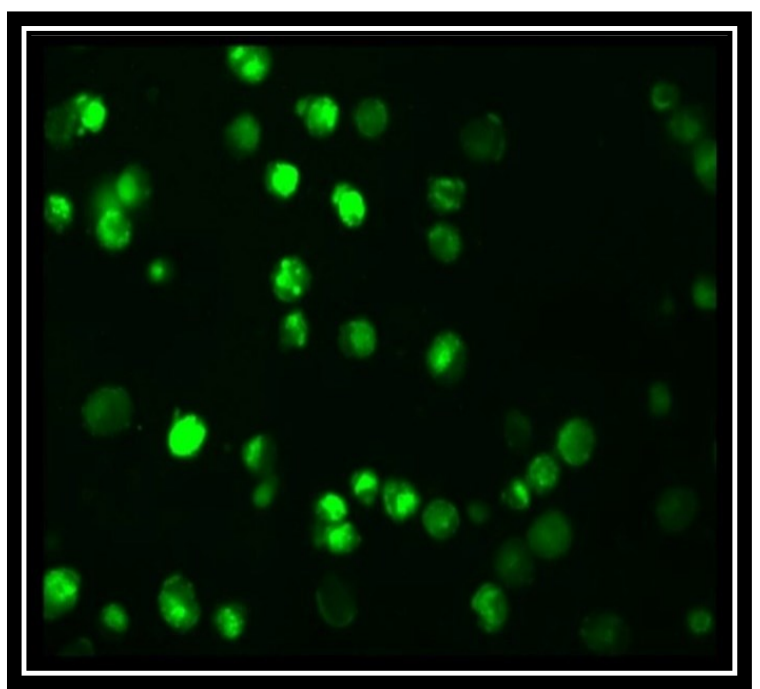

(B)

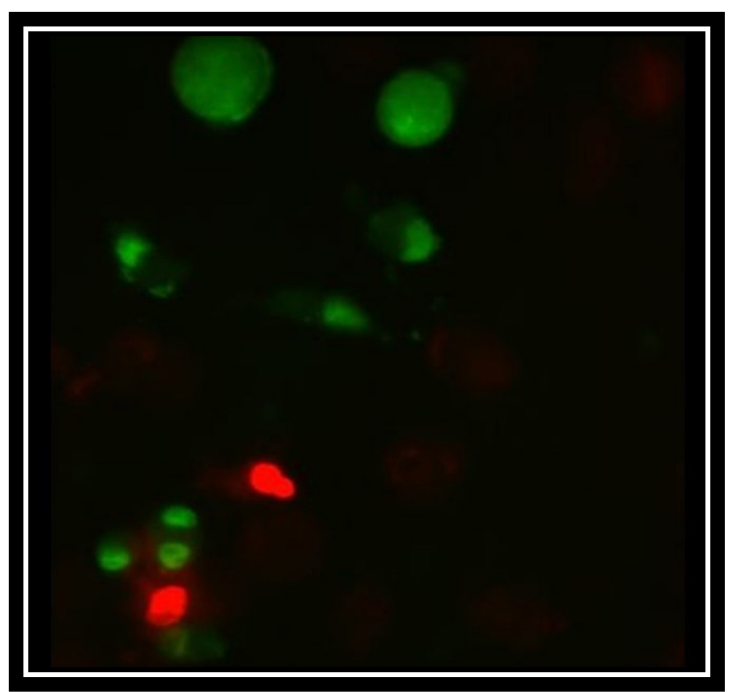

(D)

Figure: 4 (A) Negative control group (normal cells): the circular nucleus uniformly distributed in the center of the cell. (B) Experimental group (early apoptotic cells): nucleus showed yellow-green fluorescence by acridine orange (AO) staining. (C) Experimental group (late apoptotic cells): the nucleus of cell showed orange fluorescence by EB staining and gathered in concentration and located in bias. (D) Necrotic cells: The necrosis cells' volume was increased in high concentration, showing uneven orange-red fluorescence and an unapparent outline. It is becoming dissolved or near disintegration 


\subsection{In vivo Study the Effect of L1210 cell on ascites and sold Tumor}

\section{Ascites Tumor}

Table (3) \& Figure(5) show that the survival of S.glaucum treated animals exceeded that of the controls. 30 days after the tumor transplantation not a single untreated mouse was alive. At the same time, prior treated animals were alive. The first untreated animal died 10 days, the last one, 25 days after tumor transplantation. In two treated groups with and prior tumor transplantation the animals were alive (except one/group) 31 days after tumor inoculation, when the animals were

Table: (3) Survival animals \% through experimental days

\begin{tabular}{|c||c|c||c||c||}
\hline Groups & Gp1 & Gp2 & Gp3 & Gp4 \\
\hline \hline Days & \multicolumn{3}{|c||}{} \\
\hline \hline $\mathbf{0}$ & $100 \%$ & $100 \%$ & $100 \%$ & $100 \%$ \\
\hline \hline $\mathbf{5}$ & $100 \%$ & $100 \%$ & $100 \%$ & $100 \%$ \\
\hline \hline $\mathbf{1 0}$ & $100 \%$ & $90 \%$ & $100 \%$ & $90 \%$ \\
\hline \hline $\mathbf{1 5}$ & $100 \%$ & $70 \%$ & $70 \%$ & $90 \%$ \\
\hline \hline $\mathbf{2 0}$ & $100 \%$ & $40 \%$ & $50 \%$ & $60 \%$ \\
\hline \hline $\mathbf{2 5}$ & $70 \%$ & $0 \%$ & $30 \%$ & $40 \%$ \\
\hline \hline $\mathbf{3 0}$ & $40 \%$ & $0 \%$ & $10 \%$ & $20 \%$ \\
\hline \hline
\end{tabular}

sacrificed. The body weight at the end of day 15 was more compared to the day 1 in all the experimental animals. In contrast, animals in Gp3 and GP4, that were administration $S$. glaucum $(75 \mu \mathrm{g} / \mathrm{ml}, 0.1 \mathrm{ml}$; i.p ) initiated one days after transplant with L1210, appeared to have both normal body weight $34.5,33.1$ and $31.2 \mathrm{~g}$ in addition to normal animal respectively (Table:4), the non-injected group Gp1 which received only media $(0.1 \mathrm{ml}$; i.p) showed normal survival rate and body weight with normal muscular wall (Figure-7).

Survival animals $\%$

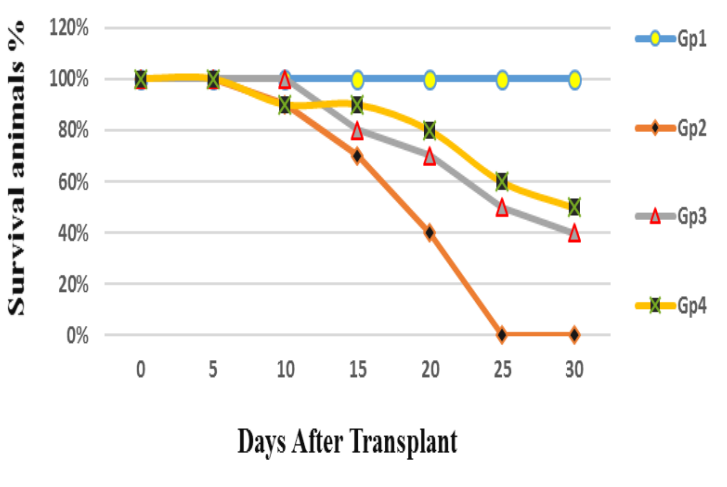

Figure: (5) Survival animals \% through the 30 day's mice were transplant intraperitonially with L1210, in days 25 no survive in Gp2 untreated mice, While Gp3 and Gp4 treated mice were showed resistant until days 30 comparing with normal animal in Gp1 
Table : (4) BodyWeights of the animal after the treatment. Illustrates that there is a difference in animal weight per day 15 where untreated Group Gp2 showed recorded the highest weight. As the two groups of treatment Gp3 and Gp4 recorded a body weight nearly to the normal group Gp1.

\begin{tabular}{|c|c|c|c|c|c|c|}
\hline \multirow{2}{*}{$\begin{array}{l}\text { Group of } \\
\text { Animals }\end{array}$} & \multirow{2}{*}{$\begin{array}{l}\text { Dose of } \\
\text { Treatment }\end{array}$} & \multirow{2}{*}{$\begin{array}{c}\text { Dose of } \\
\text { Transplantation }\end{array}$} & \multicolumn{4}{|c|}{ Animal Body Weight Kg } \\
\hline & & & Day 1 & Day5 & Day 10 & Day 15 \\
\hline $\begin{array}{c}\text { Normal Animal } \\
\text { GP1 }\end{array}$ & ----------- & -------------- & 24.3 & 27.3 & 29.8 & 31.2 \\
\hline $\begin{array}{c}\text { Sample of GP } \\
\text { 2Control } \\
\text { Untreated } \\
\end{array}$ & $\begin{array}{c}75 \mu \mathrm{g} / \mathrm{ml}, 0.1 \\
\mathrm{ml} ; \text { i.p }\end{array}$ & $\begin{array}{l}\mathrm{L} 1210\left(1 \times 10^{4} / \text { cells }\right. \\
/ \text { mouse }, 0.1 \mathrm{ml})\end{array}$ & 25.0 & 29.5 & 34.8 & 40.7 \\
\hline $\begin{array}{c}\text { Sample of } \\
\text { GP3Treated with } \\
\text { Transplant } \\
\text { L1210 }\end{array}$ & $\begin{array}{c}75 \mu \mathrm{g} / \mathrm{ml}, 0.1 \\
\mathrm{ml} ; \text { i.p }\end{array}$ & $\begin{array}{l}\mathrm{L} 1210\left(1 \times 10^{4} / \text { cells }\right. \\
\text { /mouse }, 0.1 \mathrm{ml})\end{array}$ & 26 & 28.8 & 31.7 & 34.5 \\
\hline $\begin{array}{c}\text { Sample of GP4* } \\
\text { Treated Prior } \\
\text { Transplant } \\
\text { L1210 }\end{array}$ & $\begin{array}{c}75 \mu \mathrm{g} / \mathrm{ml}, 0.1 \\
\text { ml; i.p }\end{array}$ & $\begin{array}{l}\mathrm{L} 1210\left(1 \times 10^{4} / \text { cells }\right. \\
\quad / \text { mouse }, 0.1 \mathrm{ml})\end{array}$ & 25.5 & 27.7 & 30.5 & 33.1 \\
\hline
\end{tabular}

* Prior treatment before 5 days of injected with $\mathrm{L} 1210 \mathrm{n}=10$

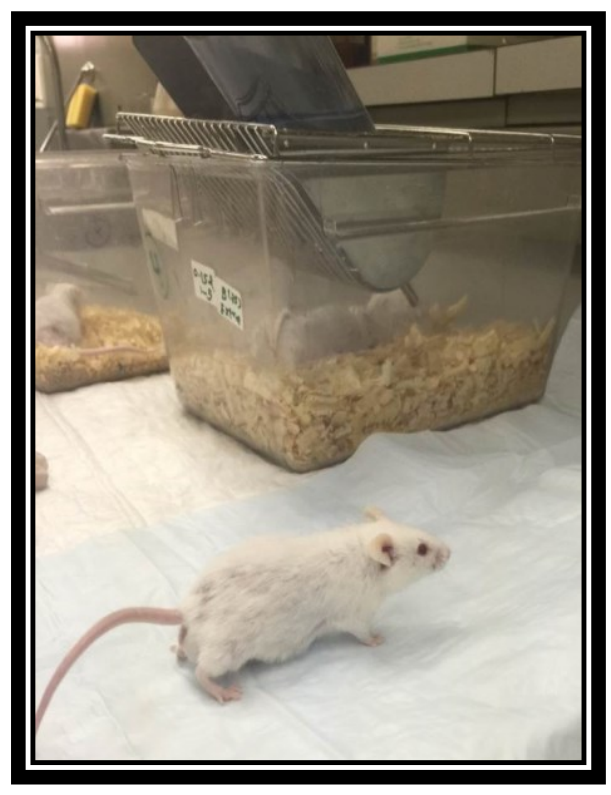

Figure-6 Normal mice without injection L1210 and treatment S.glaucum 

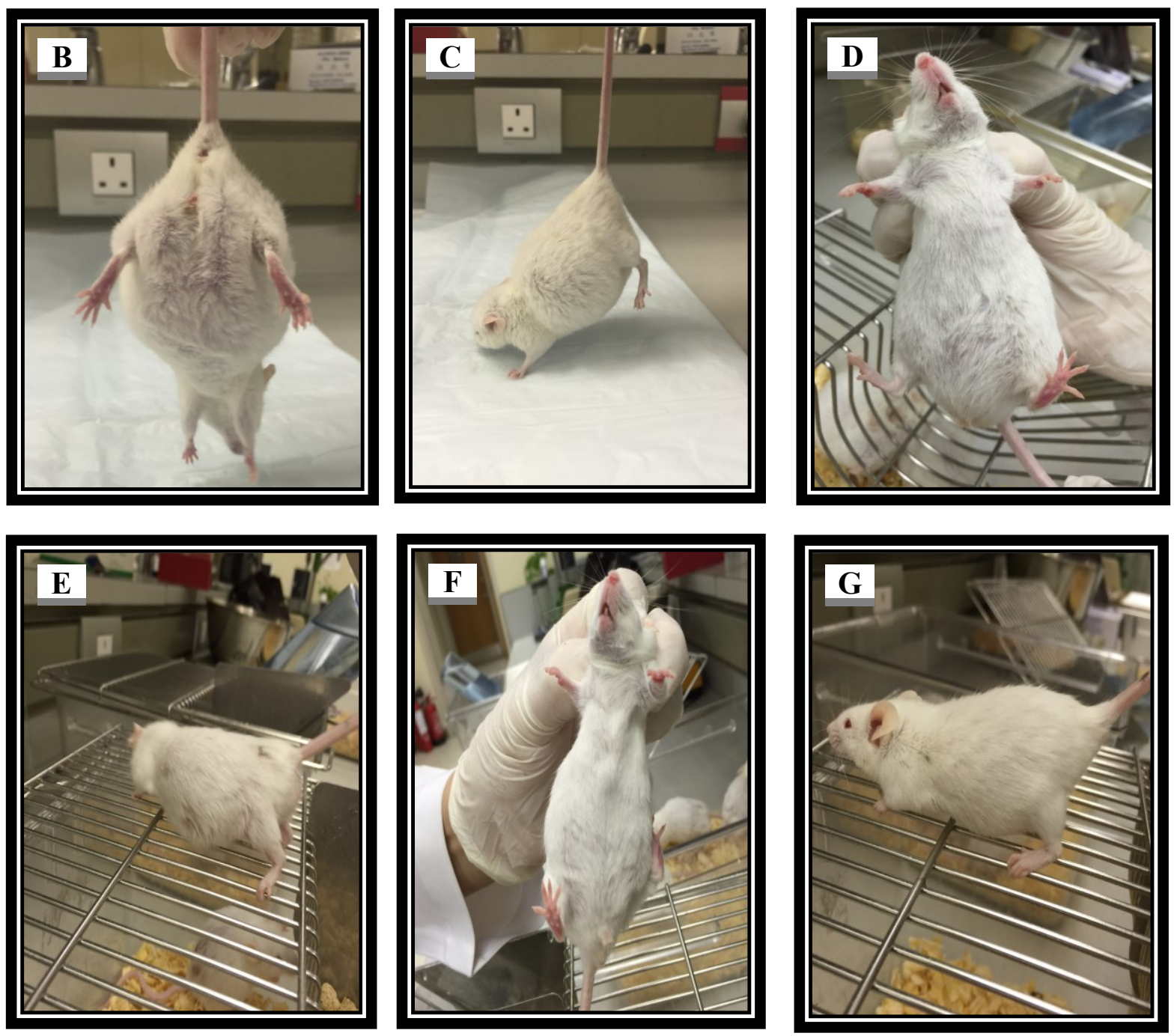

Figure-7 Experiment mice Gp2 figure (B and C) group of bearing mice injected intraperitoneal with (L1210) cells (1x104/cells /mouse) without treatment we observed copious ascetic fluid the mice have not able to move, incapable and the firs died recorded in day 10. Gp3 group of mice in figure (D and E) transplant with same previous dose of (L1210) cells, and the day next treated with S. glaucum extract concentration $(75 \mu \mathrm{g} / \mathrm{ml}$ , $0.1 \mathrm{ml} / \mathrm{g}$ body weight; i.p ) every other day the figure showed the amount of ascetic fluid less than that recorded in the previous group Gp2 and it was able to partially movement . The group Gp4 (F and G) is prior treatment 5 days before transplant (L1210) cells animal in this group seems close form normal animal and no copious ascetic fluid observed nearly body weight to normal animal, and recorded highest survival with normal animal 


\section{Discussion}

In vitro confirmation of the extract's toxicity was done on mouse leukemia cells L1210 cell lines. In this study S.glaucum inhibited the growth of L1210 in a dose dependent. Our results of the trypan blue dye exclusion assay indicates that S.glaucum extract could inhibit the growth of L1210 cells significantly in culture. ${ }^{[18 ; 19 ; 20 ; 21 ; 22]}$. S.glaucum extract induced apoptosis and not necrosis as indicated by the presence of DNA fragmentation in comet cells and apoptotic bodies found in the images ${ }^{[23 ; 24]}$. This was also corroborated by Acridine orange /ethidium bromide staining. Staining showed that the S.glaucum extract induced apoptosis in L1210 cancer cell line. Apoptosis was time and dose dependent in cell treated with 75 and $100 \mu \mathrm{g} / \mathrm{ml}$ concentrations. Our results are in agreement with the results of $[25 ; 26]$. Furthermore, in vivo study indicate that S.glaucum $(75 \mu \mathrm{g} / \mathrm{ml})$ has the ability to limit cancer progression in treated animals, owing to its antimitotic effect. Tumor size and survival rate were also improved in mouse treated with $S$. glaucum extract ${ }^{[27 ; 28 ; 29] .}$ One

of the most reliable ways of estimating the effectiveness of any anticancer drug is to observe the survival rate ${ }^{[30]}$ Our results demonstrate how S.glaucum suppresses the L1210 cells growth, by significantly reducing tumor size compared with untreated animals ${ }^{[31 ; 32 ; 33]}$ in addition to improving survival rate of mice injected with L1210 cancer cells ${ }^{[31]}$.

\section{Conclusion}

In conclusion in vitro study, we demonstrated that $S$. glaucum extract inhibited L1210 cell proliferation in a time and concentration-dependent manner by trypan blue dye exclusion test and Tetrazolium salt WST-1 kit test. The mechanism underlying cell death was due to induction of apoptosis, which was associated by DNA damage and morphological changes of the treated cells.

In vivo study indicated that $S$. glaucum has ability to suppress cancer progression in treated animals. These findings indicate that the $S$. glaucum extract can be a candidate agent for fighting cancer.

\section{References}

[1] Edwards, A.J.\& Head, S.M. "Key Environments-Red Sea "; Pergamon Press: Oxford, UK,; p. 440 (1987).

[2] Roethle, P.A. \& Trauner, D. "The chemistry of marine furanocembranoids, pseudopteranes, gersolanes, and related natural products". Nat. Prod. Rep. 25, 298-317 (2008).

[3] Blunt, J.W.; Copp, B.R.; Hu, W.P.; Munro, M.H.G.; Northcote, P.T.; Prinsep, M.R. " Marine natural products". Nat. Prod. Rep. 25, 35-94 (2008).

[4] Gross, H.; Wright, A.D.; Beil, W.; Koenig, G.M. "Two new bicyclic cembranolides from a new Sarcophyton species and determination of the absolute configuration of sarcoglaucol-16-one". Org. Biomol. Chem. 2, 1133-1138 (2004).

[5] Sawant, S.; Youssef, D.; Mayer, A.; Sylvester, P.; Wali, V.; Arant, M.; El Sayed, K. " Anticancer and anti-inflammatory sulfur-containing semisynthetic derivatives of sarcophine". Chem. Pharm. Bull. 54, 1119-1123 (2006).

[6] Sawant, S.S.; Youssef, D.T.A.; Reiland, J.; Ferniz, M.; Marchetti, D.; El Sayed, K.A. "Biocatalytic and antimetastatic studies of the marine cembranoids sarcophine and 2-epi-16-deoxysarcophine". J. Nat. Prod. 69, 1010-1013 (2006).

[7] Wahlberg, I. \& Eklund, A.M. "Cembranoids, pseudopteranoids, and cubitanoids of natural occurrence". Prog. Chem. Org. Nat. 59, 141-294 (1992). 
[8] El Sayed, K.A.; Hamann, M.T.; Waddling, C.A.; Jensen, C.; Lee, S.K.; Dunstan, C.A.; Pezzuto, J.M. "Structurally novel bioconversion products of the marine natural product sarcophine effectively inhibit JB6 cell transformation". J. Org. Chem. 63, 7449-7455 (1998).

[9] Grote, D.; Soliman, H.S.M.; Shaker, K.H.; Hamza, M.; Seifert, K. "Cembranoid diterpenes and a briarane diterpene from corals". Nat. Prod. Res. 20, 285-291 (2005).

[10] Neeman, I.; Fishelson, I.; Kashman, Y. "Sarcophine-a new toxin from the soft coral Sarcophyton glaucum (alcyonaria)". Toxicon 12, 593-598 (1974).

[11] Erman, A. \& Neeman, I. "Inhibition of phosphofructokinase by the toxic cembranolide sarcophine isolated from the soft-bodied coral Sarcophyton glaucum". Toxicon. 15, 207-215 (1976).

[12] El Sayed, K.A.; Orabi, K.Y.; Dunbar, D.C.; Hammann, M.T.; Avery, M.A.; Sabnis, Y.A.; Mossa, J.S.; El feraly, F.S. "Transformation of lactone to lactam in sarcophine and antimalarial activity of resulting N-substituted azasarcophines". Tetrahedron. 58, 3699-3708 (2002).

[13] Fahmy, H.; Khalifa, S.I.; Konoshima, T.; Zjawiony, J.K. "An improved synthesis of 7,8epoxy-1,3,11-cembratriene-15R( $\alpha), 16$-diol, cembranoid of marine origin with a potent cancer chemopreventive activity". Mar. Drugs, 2, 1-7 (2004).

[14] Katsuyama, I.; Fahmy, H.; Zjawiony, J.K.; Khalifa, S.I.; Kilada, R.W.; Konoshima, T.; Takasaki, M.; Harakuni, T. "Semisynthesis of new sarcophine derivatives with chemopreventive activity". J. Nat. Prod. 65, 1809-1814 (2002).

[15] Abouzied, A.M.; Sawant, S.S.; Sylvester, P.W.; Avery, M.A.; Desai, P.; Youssef, D.T.A.; EI Sayed, K.A. "Bioactive rearranged and halogenated semisynthetic derivatives of the marine natural product sarcophine". J. Nat. Prod. 67, 2017-2023 (2004).

[16] Hong, W.K. \& Sporn, M.B. "Recent advances in chemoprevention of cancer". Science, 278, 1073 1077 (1997).

[17] Arif, J.M.; Al-Hazzani, A.A; Kunhi, M.; AlKhodairy, F. "Novel marine compounds: Anticancer or genotoxic? J. Biomed ". Biotechnol. 2, 93-98 (2004).

[18] Patel, S., Gheewala, N., Suthar, A., and Shah, A. "Invitro cytotoxicity activity of Solanum nigrum extract against Hela cell line and Vero cell line". International journal of pharmacy and pharmaceutical sciences, 1(1), 38-46 (2009).

[19] Khairunnisa, K., \& Karthik, D. "Evaluation of in-vitro apoptosis induction, cytotoxic activity of Hymenodictyon excelsum (Roxb) Wall in Dalton's lymphoma ascites (DLA) and Lung fibroblast-Mouse L929 cell lines". Journal of Applied Pharmaceutical Science, 4 (8), 11 (2014).

[20] Neelamkavil, S. V. \& Thoppil, J. E. "Evaluation of the anticancer potential of the traditional medicinal herb Isodon coetsa ". South Indian Journal of Biological Sciences, 2(1),41-45 (2016).

[21] Chu, S. T., Cheng, H. H., Huang, C. J., Chang, H. C., Chi, C. C., Su, H. H., and Lu, Y. C. "Phospholipase A 2-independent $\mathrm{Ca} 2+$ entry and subsequent apoptosis induced by melittin in human MG63 osteosarcoma cells". Life sciences, 80(4), 364-369 (2007).

[22] Koleva, V., Dragoeva, A., Draganov, M., MELENDEZALAFORT, L., Rosato, A., Uzunov, N., and Enchev, D. "Inhibition of growth and induction of apoptosis in human lung cancer cells by Br-oxph". Genetika, 46(1), 1-10 (2014).

[23] Yedjou, C. G., \& Tchounwou, P. B. "In-vitro cytotoxic and genotoxic effects of arsenic trioxide on human leukemia (HL-60) cells using the MTT and alkaline single cell gel electrophoresis (Comet) assays". Molecular and cellular biochemistry, 301(1-2), 123130 (2007).

[24] Liao, W., McNutt, M. A., and Zhu, W. G. "The comet assay: a sensitive method for detecting DNA damage in individual cells". Methods, 48(1), 46-53 (2009).

[25] Leles, S. M., Factori, R., and Rocha, C. L. M. S. C. "In situ analysis of apoptosis in Aspergillus nidulans with ethidium bromide and acridine orange". Genetics and molecular research: GMR, 12(3), 2895 (2013).

[26] Krishnaveni, M., \& Suresh, K. "Induction of apoptosis by quinine in human laryngeal carcinoma cell line (KB)". Intrnational journal current resersh Academy of management review, 3(3), 169-78 (2015).

[27] Moshref, S. S., Khorshid, F. A., and Jamal, Y. S. "The effect of PM 701 on mice leukemic cells: I-tissue culture study of L1210 (in vitro) II-in vivo study on mice". Medical Science, 13(1) (2006).

[28] Cunderlíková, B., Vasovič, V., Sieber, F., Furre, T., Nesland, J. M., and Peng, Q. "Hexaminolevulinatemediated photodynamic purging of leukemia cells from BM". Bone marrow transplantation, 45(10), 1553-1561 (2010).

[29] Prasad SB, \& Giri A. "Antitumor effect of cisplatin against murine ascites Dalton's lymphoma". Indian J Exp Biol. 32(3), 155-62 (1994). 
[30] Mazumder UK, Gupta M, Maiti S, Mukherjee M. "Antitumor activity of Gygrophila spinosa on Ehrlich ascites carcinoma and sarcoma-180 induced mice". Indian J of Experimental Biology 35, $473-477$ (1997).

[31] Balakrishnan, S., Manmeet, S. S., and Ajay Sh, N. M. "Anti-tumor effect of acetone extract of Madhucalongifolia against Ehrlich Ascites Carcinoma (EAC) in mice". Phytopharmacol, 3(1), 130-6 (2012).

[32] Weinstein, J. N., Magin, R. L., Cysyk, R. L., and Zaharko, D. S. "Treatment of solid L1210 murine tumors with local hyperthermia and temperature- sensitive liposomes containing methotrexate". Cancer research, 40(5), 1388-1395 (1980).

[33] Elerian, A. E., Khaled, U. A., and Ahmed, S. R. "Effect of low intensity ultrasonic on ehrlich solid tumor in vivo". European Scientific Journal, 9(21). (2013). 


\section{تقييم النشاط المضاد للتسرطن لخلاصة المرجان الناعم ساركوفيتون غلاكم في خلايا ابيضاض

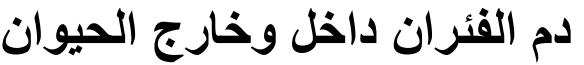
نجاح محمد حميد البقمي'، اسامة عبد الله ابوزنادة '، محد زكي مصطفي العسولي' ، محمد علي المطري'، ياسر انور' و سفيان

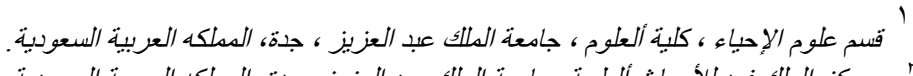
مركز الدلك فهل للأبحاث ألطبية، جامعة الدلك عبد العزيز، جدة، الملكه العربية السعودية.

الهستخلص: إن التتوع البيولوجي للبيئة البحرية يفتح آفاقا جديدة في البحث عن مركبات نشطة بيولوجيا بمكن استخدامها كعوامل مضادة للأورام. المرجان الناعم ساركوفيتون غلاوكوم هو من الثعب المرجانية الهامة في البيئة البحرية. فهو يتمز بخصائصده المضادة للأكسدة،

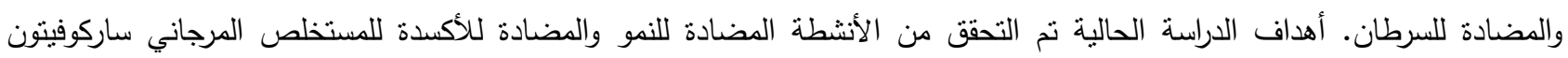
غلاوكوم باستخدام الخلايا السرطانية من نوع الليوكيميا أيضا، قمنا بتقييم نشاط المستخلص المرجاني ضد خلايا اللوكيميا على الفئران الحية داخليا (الفئران البيضاء السويسرية). نم تحديد الأنشطة المضادة للنمو والأنشطة السامة للخلايا باستخدام صبغة التريبان الزرقاء واختبار تكاثر الخلابا. وقد تم التحقيق في الآلية الكامنة الكامنة وراء موت الخلايا سواء كان نخر أو الموت الخلوي المبردج باستخدام تجربة الرحلان

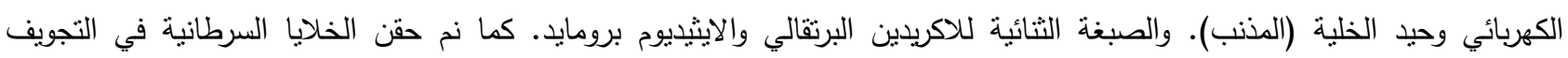

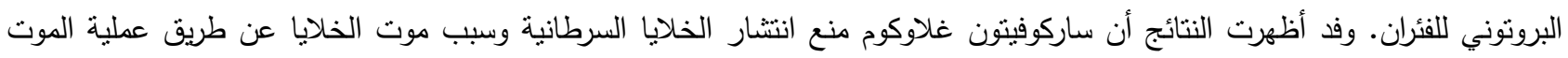
الخلوي المبرمج. الذي كان مرتبطا بتلف في الحضض النووي وتغير شكل الخلايا المعالجة. وقد تم التحقق في الدراسة التي أجريت ووجد أن

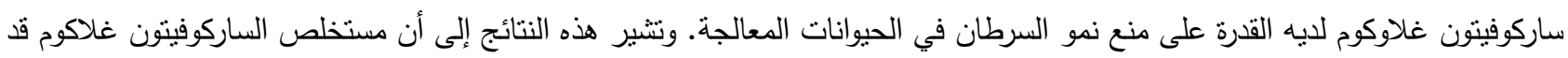
يكون عاملا مرشحا لمكافحة السرطان. كلمات مفتاحية : الثعب المرجانية ، المضادة للسرطان ، المضادة للأكسدة 